\title{
Coastal Erosion Management at Callao (Peru) in the 17th and 18th Centuries: The First Groin Field in South America?
}

\author{
Carlos Mestanza ${ }^{1,2}$ (D), Marco Piccardi ${ }^{3}$ and Enzo Pranzini ${ }^{3, *}$ \\ 1 Facultad de Ciencias de la Vida, Universidad Estatal Amazonica, Sucumbos EC210150, Ecuador; \\ cmestanza@ug.uchile.cl \\ 2 Research Center, Green Amazon, Nueva Loja EC110150, Ecuador \\ 3 Dipartimento di Scienze della Terra, Università di Firenze, 50121 Firenze, Italy; m.piccardi@tin.it \\ * Correspondence: epranzini@unifi.it; Tel.: +39-055-275-6547
}

Received: 6 June 2018; Accepted: 27 June 2018; Published: 4 July 2018

\begin{abstract}
Analysis of written documents, projects and historical cartography of the 17th and 18th centuries allows reconstruction of the shore protection works performed at Callao (Peru) to defend the settlements and its boundary wall from storm waves and tsunamis. Groins appeared for the first time in early 18th century maps, together with gently sloping revetments in an unrealized project of the same period. Comparisons between Callao projects and those performed in Europe in the same centuries show a uniformity in design and construction materials that overpasses the environmental differences of the sites. Successes and failures followed each other and, although an understanding of coastal dynamics and the positive and negative effects of the various works were known, it was not possible to guarantee the stability of the walls and consequently the safety of the city from sea attack. A strategic retreat was even considered.
\end{abstract}

Keywords: historical cartography; shore protection structures history; groins; gently sloping revetment; earthquake; tsunami; strategic retreat

\section{Introduction}

Coastal erosion, because of sea level rise, subsidence, reduced river sediment input and, more recently, anthropogenic interventions on the watershed, is a natural process that humans have tended to oppose ever since they settled near the shoreline [1]. At sites, the construction of ports, docks, piers, breakwaters along the coast itself induced or increased the process [2]. In some areas, hurricanes e.g., [3] and tsunamis e.g., [4] transformed this slowly-evolving process into a catastrophic one. Nevertheless, coastal settlements increased and expanded during the centuries, thanks to their advantageous position for climate, resources access, movements and-recently—recreation [5].

Where it was not possible to retreat, shore protection structures had to be built to hold the current position, either for the need to stay close to water (commercial, military, industrial purpose) or because safer land was unavailable; frequently, it was investment on reclamations done in that specific area that discouraged retreat.

Different materials were used in the past (rock, wood, fagots) in a variety of configurations, such as revetments, rip-raps, seawalls, detached breakwaters, and groins. Most ancient structures were subjected to continuous and expensive maintenance, and now are lost, either because land was abandoned to the sea (generally rural areas) or because they have been continuously replaced with stronger ones.

Elsewhere, military defences (e.g., boundary walls) also served as shore protection structures, such as seen in Roman and pre-Roman maritime cities. To reconstruct the evolution of these defence 
structures, written documents, drawings, and old maps are the main sources of information. It is known that earth and stones were used for seawall construction in 713 AD at Quintang Estuary (China), further replaced with bamboo baskets filled with stones in 910 AD [6], and rock seawalls were built in China in the 14th century [7]. Due to the widespread coastal accretion that characterized Europe until the 18th century (generally as a consequence of deforestation), protection works of the coast were carried out in limited areas, mostly along the North Sea coast. Nieuwhof [8] referring to the excavations carried out by Bazelmans [9], and by Bazelmans et al. [10] describes the northwest Friesland dikes (no more than $70 \mathrm{~cm}$ high, composed of neatly-stacked peat sods against a core of loose bulk material) of Peins-Oost (1st century B.C.) and Dongjum-Heringa (2nd century A.D.).

Dykes have been present since the medieval period: in Germany since the 11th century to oppose storm surges [11], the 12th century in the Netherlands-frequently associated with land reclamation [12], the 14th century in Belgium [13], and the 16th century in Denmark [14]. These were frequently made by materials found in situ: sand plus clay and peat reinforced with wood or fagots, and these materials were used, in different combinations, when rocks became unavailable. Importing rocks and stones from Scandinavia was expensive and its use in coastal protection was parsimonious. Building with fagots (fascinage) is a long-lasting tradition in protection of river banks and coasts. As fascinage works are nowadays used in several undeveloped countries, one may infer that many centuries ago they were present all over the world's coasts, where erosion was threatening settlements or cultivated areas. More sophisticated, but still primitive structures include gabions made of twigs and branches, in the manner of basket-work filled with pebbles and laid one on top of the other when they had to reach a greater thickness (Figure 1).

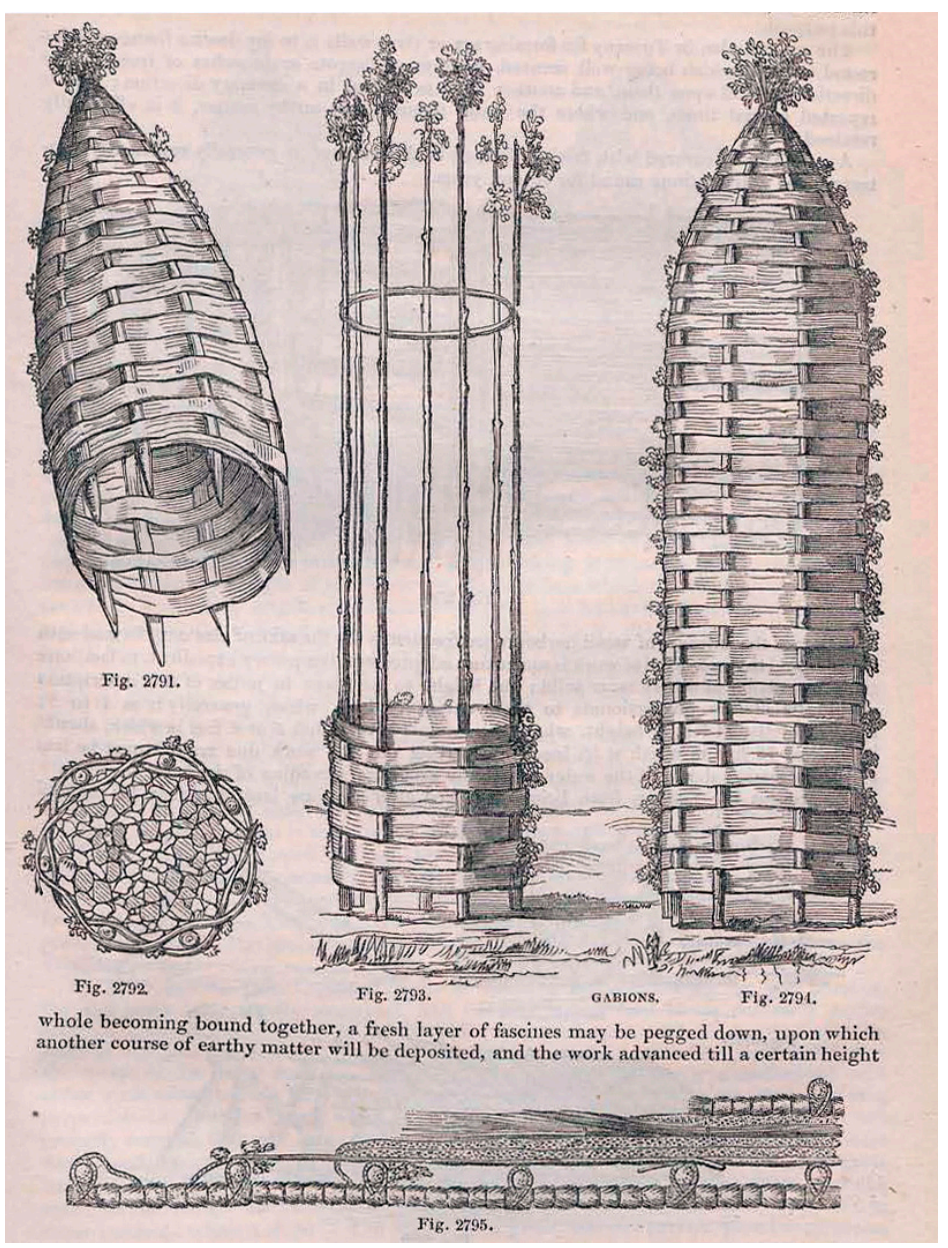

Figure 1. Gabions construction scheme by Cresy [15]. 
Groins built with these "technologies" were located on the sea side of fortified cities in the 16th-18th centuries, as shown in several ancient maps, e.g., Flissingen (Figure 2) and Ostende (Figure 3). Their functioning was to prevent scouring (and therefore collapsing), affecting structures directly exposed to wave actions due to longshore transport, backwash and, to a lesser extent, direct cross-shore wave action [16]. On account of this, for any tower, fortress and walled town located on the beach, it was of outmost importance to prevent such a process, and this was frequently achieved by constructing groins, which intercept longshore transport. On the other hand, vertical breakwaters were built by the Romans just to prevent harbor entrance siltation; but in this case a stout rock foundation was laid at the base [17].

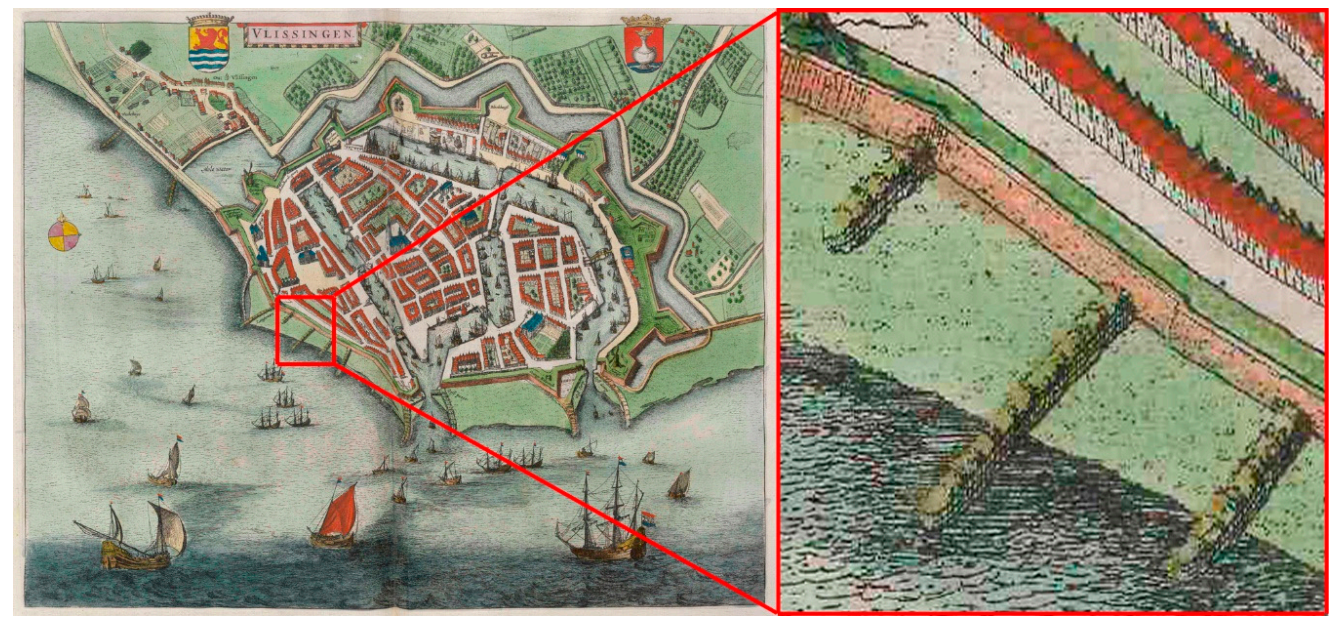

Figure 2. Groins at Flissingen (The Netherlands) in a 1649 map (ed. 1652) by Joan Blaeu [18]. Courtesy Universiteitsbibliotheek Utrecht.

Maps do not always allow identification of the design of individual groins and the material used, but in some cases, pictures can be extremely detailed and annotations give further information. For example, Figure 2 shows several shore protection structures made up of wood piles boxes, but it is impossible to see what lies inside. More explicative is the 1734 map of Ostende (Figure 3), where groins are better drawn and writing in Latin Cistae ligneae lapidibus repletae and in Frisian Holtzerne Kuften mit steunen ange fillet explains that they are formed by wood baskets filled with stones [19]. Siltation, in this case and in that of Flissingen, was not a problem for navigation and beaching, since access to the town was guaranteed through the river mouth or channels entrances protected by jetties.

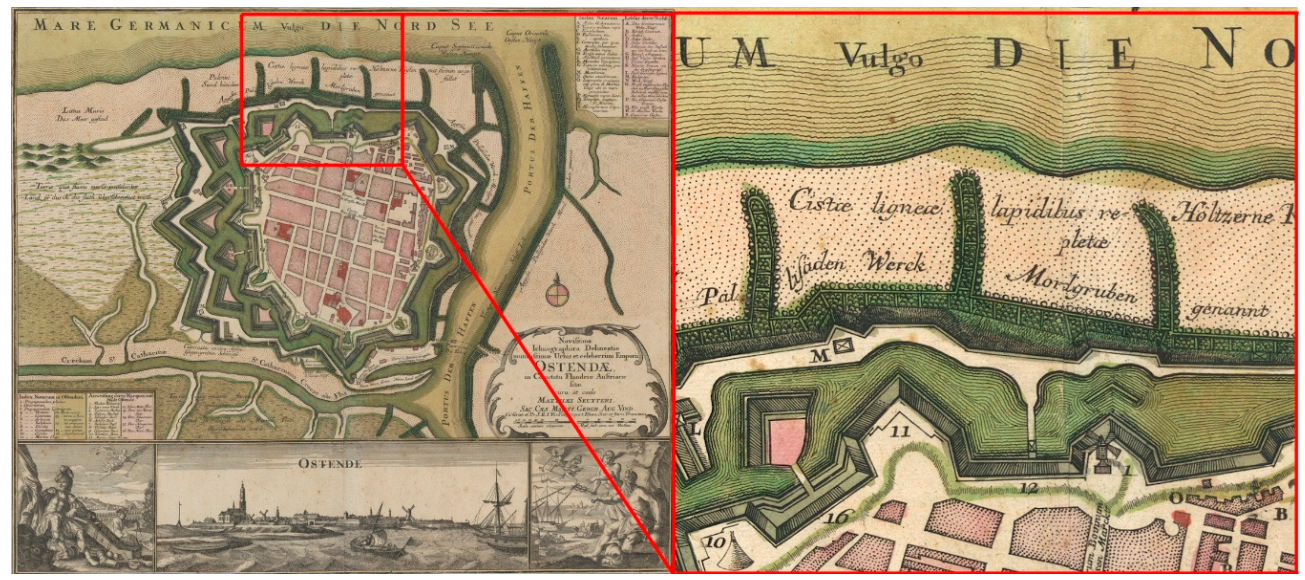

Figure 3. Ostende in a 1734 map by Seutter [20] (detail on the right). 
These vernacular structures, known from antiquity, are still present in many countries where local coastal populations struggle against the sea. Being recently adopted by "green engineering", the knowledge of their design and efficiency could help future projects.

\section{Materials and Methods}

For the present study, approximately 50 maps, plans and views drawn or printed from the 17th to 18th centuries, representing the port of Callao and its surroundings, were analyzed. Further, several texts were analyzed, both accompanying the previous documents and independently. They were the result of European expeditions to the South Seas, organized by different navies (Spanish, Dutch, French, English, etc.) and their content cannot be ignored for a full comprehension of the historical iconography. In addition, there are drawings apparently isolated from any context, whose collocation is more difficult.

On this matter, a comparative, synchronic and diachronic analysis was performed to identify original documents and locate them in true time, discarding late copies or variants, which frequently constitute a trap for hasty scholars.

In this analysis, one must be aware of the fact that maps and drawings had a strategic importance, and copyists in the service of the various countries were reproducing documents, frequently stolen, to enemies of competing fleets. On the other hand, publishers and booksellers were deleting original dates and adding a more recent one to make the book more inviting and to sell out remnants [21]; similarly, maps were "updated" only changing their age [22].

In this case, dating is even harder. Evidences of this state of things comes from the scene at Callao published in 1729 within a collection of views by van der Aa [23] (Figure 4), being nothing else, but a reproduction of a 1671 Dutch view [24]. These older documents actually were probably inspired by the view of the naval blockade of Callao in May 1624 by the 11 ships of the "Nassau Fleet" under Jacques $l^{\prime}$ Hermite [25], and Figure 5. In this case, the state of the wall and of the beach, which is our interest, is very likely to be that of 1624 and not of 1729 .

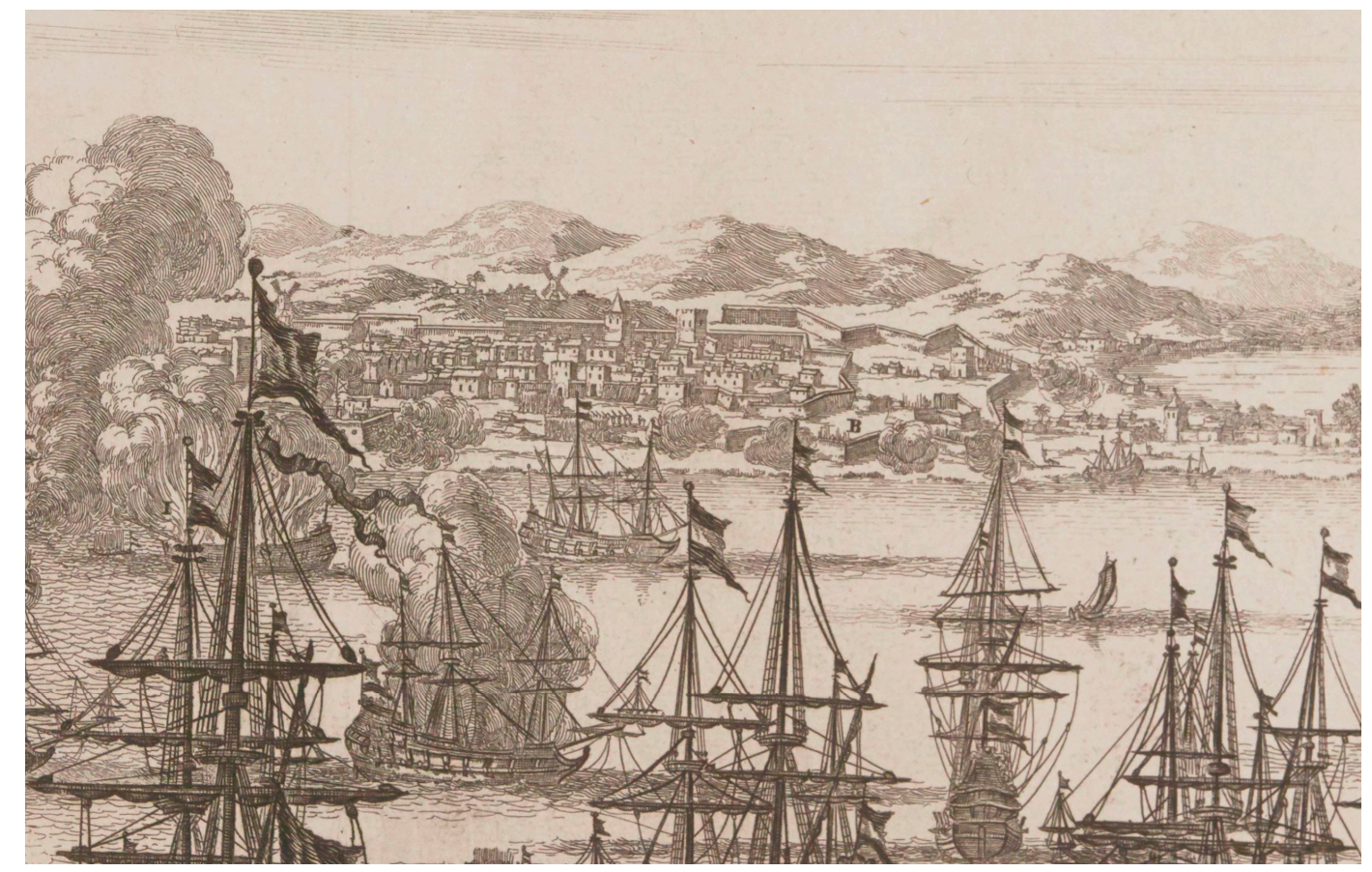

Figure 4. The first wall of Callao in a detail of a view published in a collection dated 1729 by van der Aa [23], which is actually a reproduction of a 1671 Dutch view. Courtesy: Bibliothèque nationale de France. 


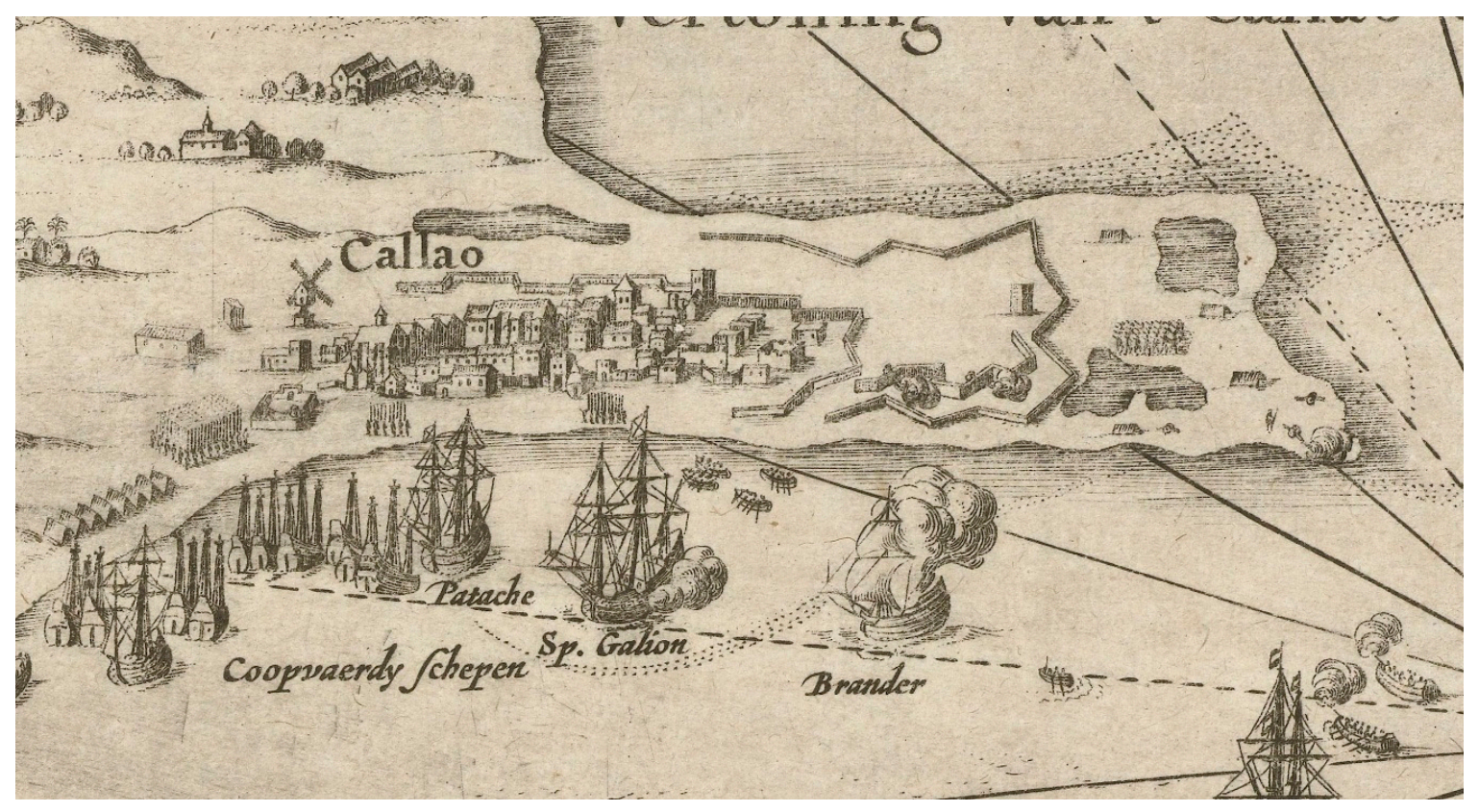

Figure 5. Callao in a 1624. Detail of view by an unknown author published in ca. 1663 [26]. Courtesy: Rijksmuseum, Amsterdam.

As far as accuracy is concerned, Callao maps and views used in this study, although not suitable to quantify beach evolution, can give accurate information on the presence/absence of coastal structures and on their effect on coastal morphology (i.e., silting side), especially when flanked by written descriptions.

\section{Shore Protection at Callao}

The Peruvian coast stretches along the north-west South America continental margin, a very tectonically active area [4] exposed to earthquakes, landslides, floods, sea storms and tsunamis. Callao, the most important harbour in Peru (Figure 6), had to face these catastrophic events since its foundation in 1537. Its first boundary wall, built at the beginning of the 17th century, was replaced by new walls between 1640 and 1647 [27]. These primarily had a military function, but on its sea side they also had to protect the settlement from wave attack, which proved to be stronger than that of any enemy's fleets, as written in chronicles and shown in Figure 7.

The history of the town and of its walls has been recounted by Melo in 1899-1900 [29], Arrũs in 1905 [27] and later by Lohmann Villena in 1963 [30]. They, and mostly the latter, gave a detailed account of the evolution of the settlement and its defensive structures from an historical perspective, but also provided sound technical information on the shore protection structures built to defend the town from the sea; these stimulate a comparison with present day knowledge of coastal engineering.

The area where Callao was built in 1537 has been inhabited since the pre-ceramic period (Cotton pre-ceramic, 2500-1750 B.C. [31], but no buildings are drawn on a 1624 view, except those forming a small colonial settlement (Figure 4), which quickly became the most important harbour on the South America Pacific coast.

A detailed analysis of 17th century events is provided by Lohmann Villena [30]. According to his reconstruction, the fence present on the 1624 map was not completed, and between 1640 and 1647 new walls were built, but their seaward side segment soon had structural problems, mostly due to overtopping by storm wave attacks in 1647 and 1651.

Anyhow, the coup de grace to the city and walls occurred with the 1655 earthquake (estimated magnitude 7.4 with epicentre in front of Isla de San Lorenzo [32]) and the following tsunami, which destroyed part of the walls, the Jesuit Church and the Viceroy residence. A further storm 
in 1656 created additional damages in the unprotected town. According to Lohman-Villena [30], to replace the collapsed wall segment, a breakwater (18.50 m long, $3.36 \mathrm{~m}$ wide and 4.20 high) was built. However, breaches created by further earthquakes are visible in the map copied by Lemoine [33] and attributable to the years 1724-1727 (Figure 7).

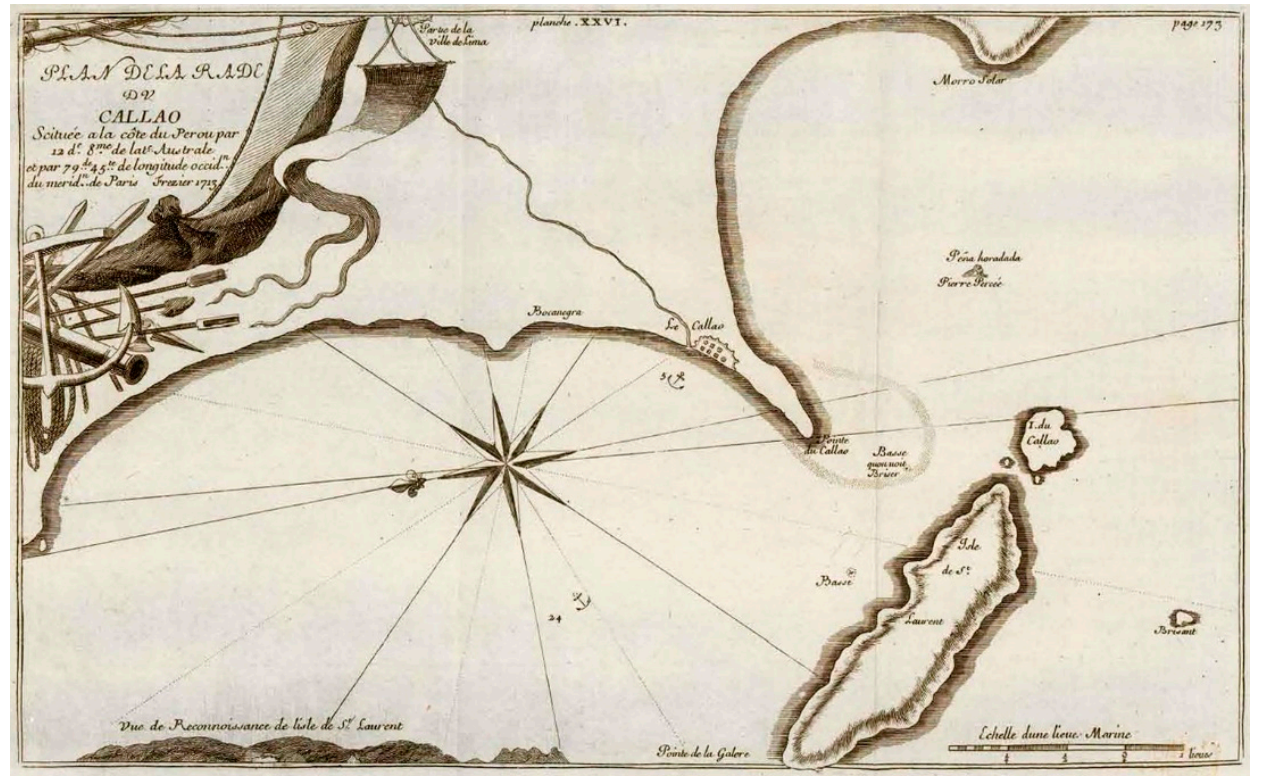

Figure 6. The bay of Callao and Isla San Lorenzo in a map surveyed by Frézier [28] in 1713 and published in 1716. Courtesy: Zentralbibliothek, Zürich.

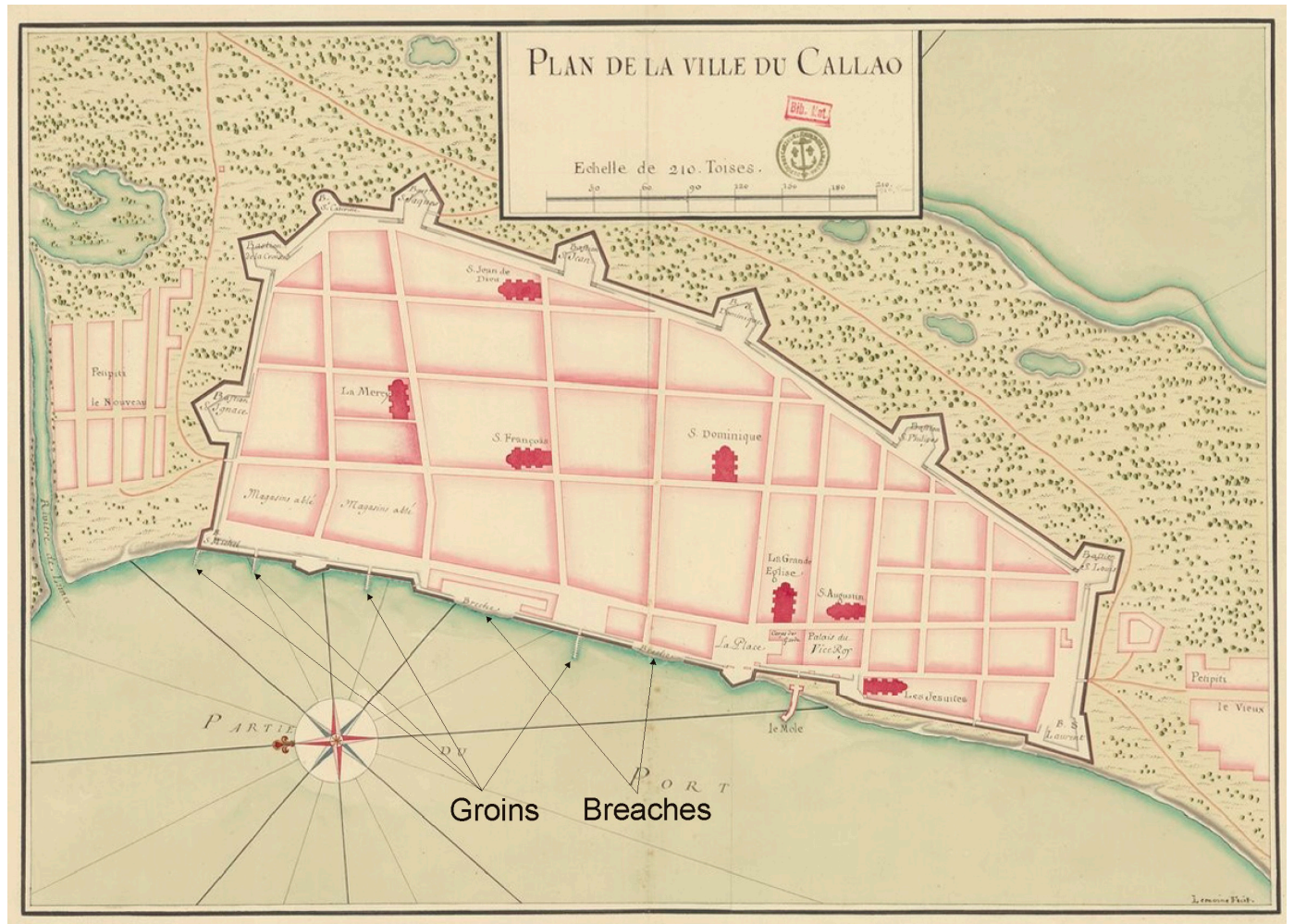

Figure 7. Groins in Callao (1724-1727) in a city plan copied by Lemoine [33]. Courtesy: Bibliothèque nationale de France. 
Earthquakes continued to hit Callao even in the following decades, and the continuous interventions did not stop wall deterioration. After the 1687 earthquake, repairs were done on the seaside wall placing masonry and planting a crescent-shaped fence with three rows of stakes filled with stones [30] (p. 132). In 1694, a pier was built, which extended it some $60 \mathrm{~m}$ further (Figures 7-9) with stones brought from the neighboring San Lorenzo island (Figure 6). This pier (stonekey) worsened the wall stability condition, as realized by Frézier during his visit in 1713: This Port was in a bad Condition in the Year 1713; there were five Breaches in it, and the Sea daily ruins the Wall, fince there has been a Stone Key built, the Situation whereof stops the S. W. Surf, and occasions a Return of the Water, which saps the Walls of the Town [28] English edition [34] (p. 196).

Between the end of the 17th and the beginning of the 18th century, several gabions were built using piles from straight trees coming from Guayaquil (Ecuador), each 7 to $9 \mathrm{~m}$ long and $0.5 \mathrm{~m}$ in diameter, locked with ribbons and nailed. Using a pile driver, they were hammered to a depth of 2 to $2.5 \mathrm{~m}$, their interstices being filled with large stones, as reported by Lohmann Villena [30] (p. 134).

In the 18th century, the rise of the Bourbon dynasty in Spain and the pacto de familia with France increased the presence of French military engineers in Spanish colonies. From 1707 to 1711, Jean Baptiste de Rosmain was in charge as Inspector of Callao fortifications. To prevent enemies from climbing over the wall, he eliminated sand that had accumulated against it [30] (p. 137).

Maybe protection of the wall from sea attack was deputed to a glacis qui règne le long de la cité nouvelle muraille bien pavè et entrelassè de gros madriers jusques au bord de la mer (gently sloping revetment running along the wall and well paved with sheet interlaced with large planks up to the shore line; as in Figure 9 map cartouche).

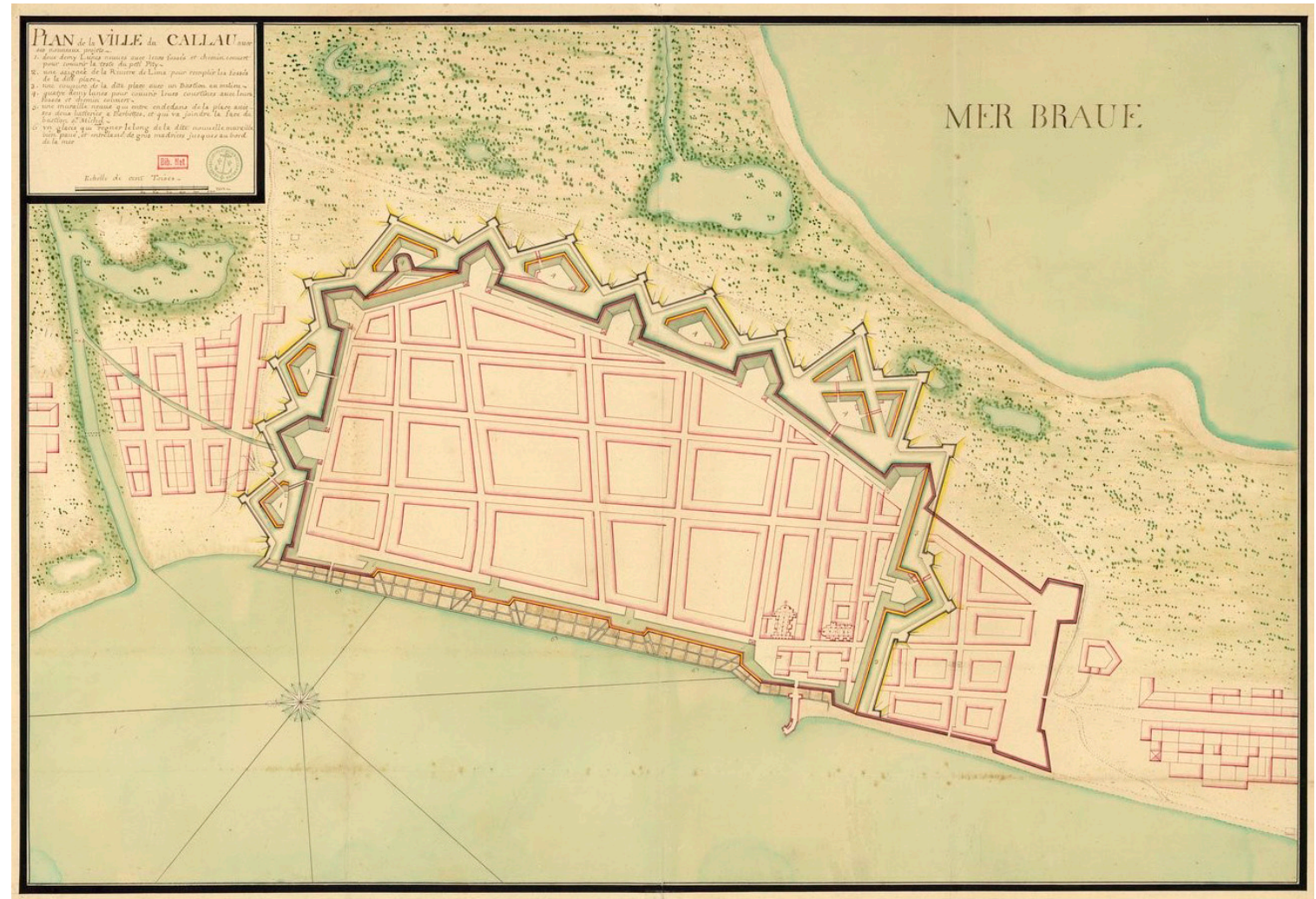

Figure 8. Callao: project of the walls and of their protection on the sea side formed by wooden board boxes filled with well-arranged stones [35]. Courtesy: Bibliothèque nationale de France. 


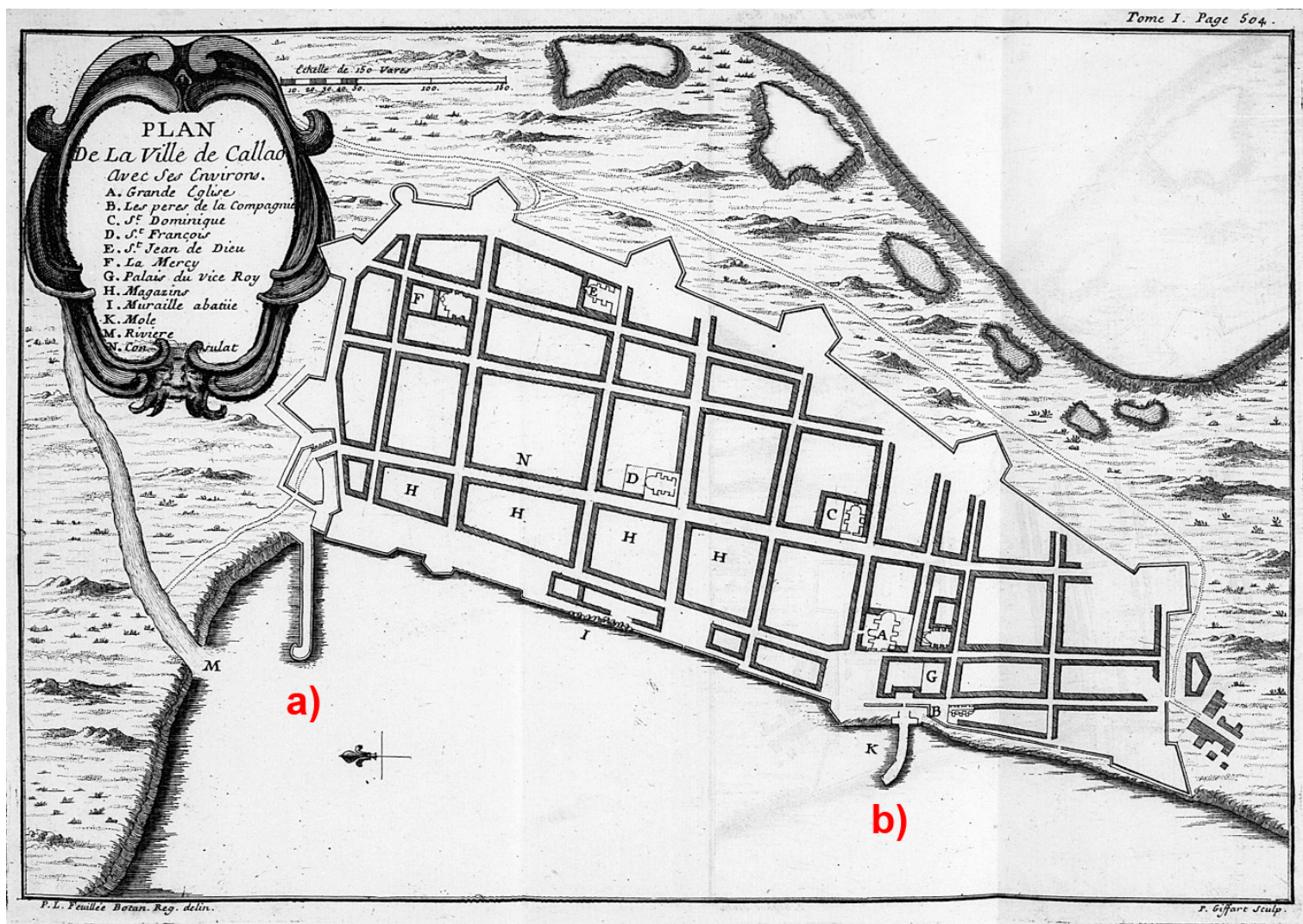

Figure 9. Callao in a city plan drawn by Feuillée [36], in 1710 (1714 ed). On the eastern side of the town, the jetty designed by de Rosmain and never realized (a); on the western side the 1694 jetty (b). Courtesy: ETH-Bibliothek Zürich.

This unrealized project is known thanks to a drawing by Lemoine [35] (Figure 8)—probably the cartographer François-Pierre Le Moyne, 1713-1795-employed at the Dépot des cartes et plans of the French navy, where he worked also as a map copyist at reproducing, inter alia, many maps of South America. De Rosmain also designed a jetty to be built on the eastern side of the town to host water supply boats, which is visible on a map by Feuillée dated 1710 [36] (Figure 9), but never realized. In any case, no intervention had the desired effect, so that in the 1720s the hypothesis to rebuild Callao further from the sea was advanced-a forerunner project of strategic retreat.

After de Rosmain's death, the responsibility for Callao's defensive structures was inherited by Pedro de Peralta Barnuevo, mathematician and astronomer, later assisted by engineer Nicols Rodriguez. The latter, as previously done by Frézier, paid attention to wall scouring induced by the 1694 jetty. To prevent this process, they proposed to build groins to intercept longshore transport in order to create a beach in front of the walls. They were placed 'at proportional distances so that the effect of each reached to the next' [30] (p.143). Construction started in 1724 and Figure 7 is very likely related to the first construction step, with four out of the eight designed groins, which appear in Figure 10.

Here, the groin length/spacing ratio is approximately $1 / 2-1 / 4$, similar to values found in most groin fields today [38]. Four shore parallel gabions lines were built between the groins with the purpose of retaining sediments dragged by waves. No information was given on the construction material, but from the drawing they seem very similar to the cistae ligneae present at Ostenda (Figure 3).

The analysis of hundreds of maps representing 17th-18th century coastal settlements in South America shows that no other groin-based shore protection project was performed before 1724 . We wait till 1779 to see the construction of a groin field at Cartagena de Indias (Colombia), but inside a detached breakwater [39]. 
In Figure 10, groins are silted on the west side, demonstrating an eastward longshore transport, confirmed by the fact that Rio Rimac, the main feeder of this coastal segment [40] empting to the east of the town, does not create a beach in adherence to the breakwater of the present city port. In addition, the delta formed during the March 2017 catastrophic flood (El Niño event, 10 times the average rainfall of that month) could not reach the breakwater. Wave reflection today on that oblique structure can be thought of as an additional process to limiting river sediment dispersion to the west.
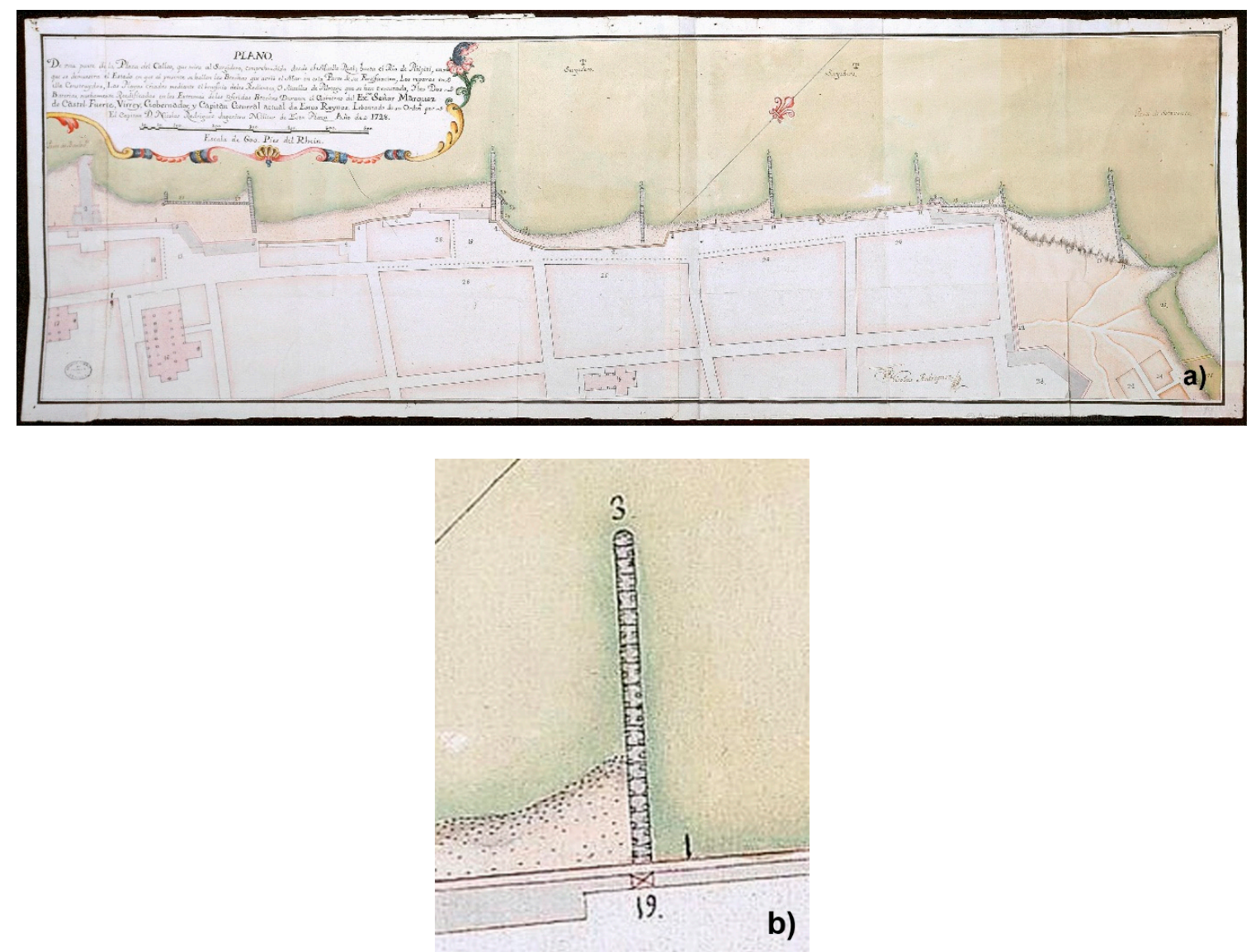

Figure 10. (a) Groins at Callao in 1728; (b) Detail on a groin [37]. In the cartouche: Map of a part of Callao $(. .$.$) in which the state of the breaches done by the sea in this part of the wall is shown, together$ with the repairs done, and the beach created, thanks to the positive effects of the constructed groins ( ... ). Courtesy: Archivo general de Indias, Sevilla.

On 28 October 1746, another catastrophic earthquake (estimated magnitude 8.4 with epicentre on the northern coast of the Lima department [32]) followed by a tsunami, completely razed the town; a belt of $5 \mathrm{~km}$ of land was flooded and 4800 out of the 5000 inhabitants of the town, died [29]. A surely minor loss was the destruction of any shore protection structure that might have been built on that coast, probably the oldest groin field in South America.

For years, the various viceroys, well aware of the area's hazards, gave up reconstructing the town, again, indirectly interpreting the idea of relocation proposed a few decades previously. Defence Military protection of the landing place was commissioned to Real Felipe fort (Figure 11), whose construction started immediately after the earthquake. Nevertheless, an aggregation of spontaneous buildings near the fort recreated a town, although without a master plan.

During the 18th century, only a short extension in L shape of the 1694 jetty was performed to give shelter to the boats, but in an 1865 map, an oblique breakwater protects both a mooring area and a landfill where the railway arrives. Callao was becoming an industrial settlement with 
dockyards, carpentry, ice and sugar factories. Today, this segment of coast is almost fully armoured, with harbours, marinas, docks and revetments, whereas the areas behind hosts industries and storage yards, with residential settlements on the southern stretch only, where a narrow beach still exists. Approximately 800,000 inhabitants live in this suburb of Lima.

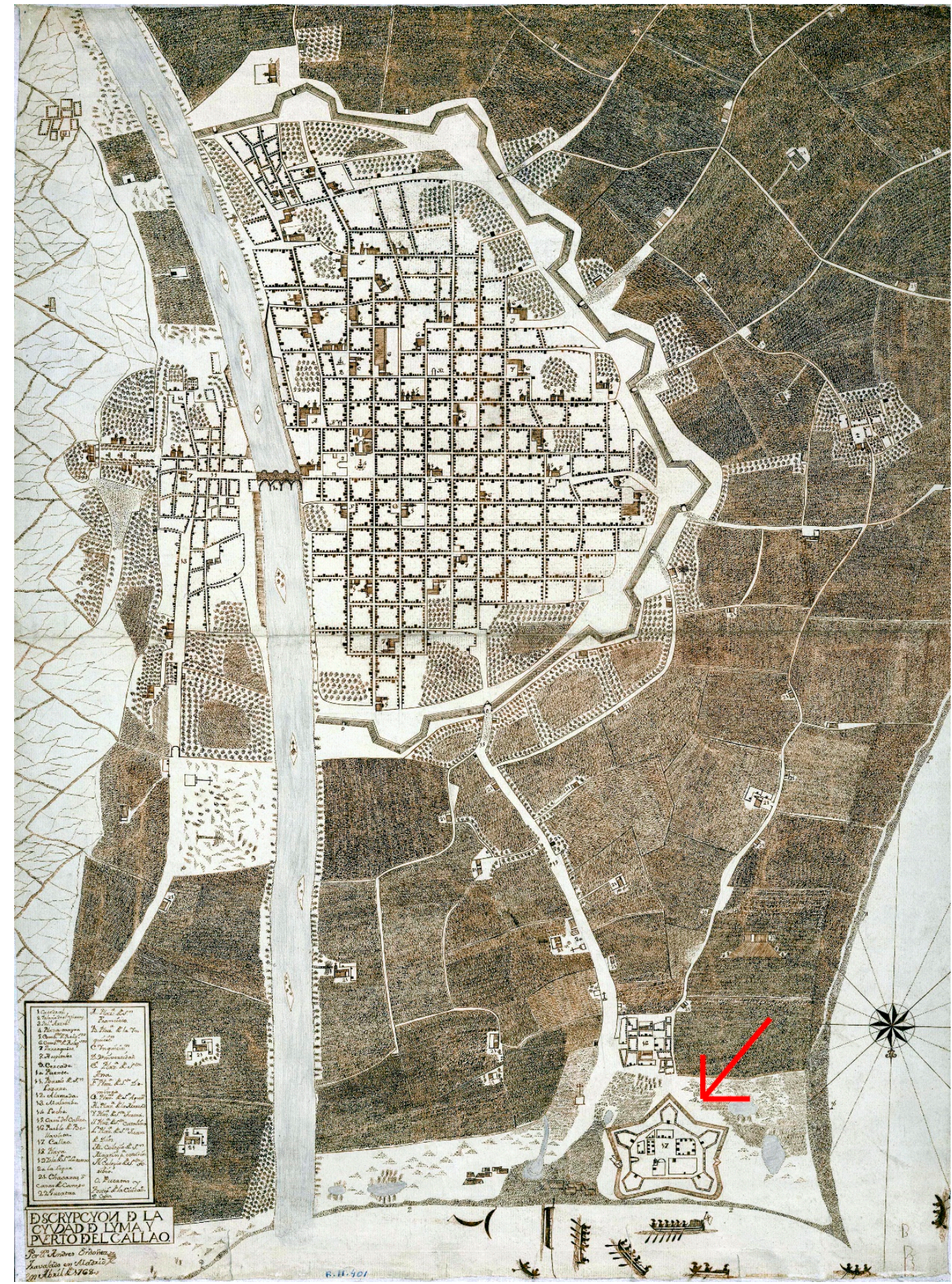

Figure 11. A 1768 copy by Ordoňez [41] of a map of Lima and surroundings (1747-1768), with Real Felipe fort (see red arrow) built on the site where Callao was present (courtesy: Biblioteca Nacional de Espana). 


\section{Conclusions}

The history of shore protection structures is a pillar within coastal engineering science, not only to reconstruct the evolution of concepts still in progress, but also to discover forgotten experiences that may help in soft shore protection strategies. What happened at Callao is still mostly hidden, but what appears from ancient maps and written documents traces a straight line with what was happening in Europe in those centuries [42]. This is not surprising, the designers being Spanish or French. However, noteworthy is the fact that structures used in Europe were replicated in a very different environment. It is evident that Callao's groins were designed within a colonialist mind set, therefore following European technology, but the presence of similar structures (for shape and construction materials) along the coasts worldwide, including rural beaches of developing countries, demonstrates the plurality of their birth site.

However, building and maintaining a groin field needed the backing of wealthy investors, an unusual occurrence in pre-17th century South America. This supports the hypothesis that the groin field at Callao, the first gold and silver exporting harbour in South America, is the oldest in that continent. In addition, a current study based on approximately 40017 th-18th maps of coastal settlement in that continent did not find similar defences older than those shown at Callao.

Reading Callao's shore protection structures' history put in evidence that most of what we know today regarding coastal dynamics and shore protection was just known in the 17th to 19th centuries. The main difference is that new materials to build structures and physical and numerical models to design them are now available.

However, within the forecasted sea level rise and increased storminess [43], strategic retreat is the most sustainable solution, at least where it is possible [44]. The same solution was proposed for Callao, just at the beginning of the 18th century.

Author Contributions: Historical and environmental analysis, C.M.; historical cartography, M.P.; coastal engineering, E.P.

Funding: This research received no external funding.

Acknowledgments: We are grateful to Allan T. Williams for advice relevant to improve this paper.

Conflicts of Interest: The authors declare no conflict of interest.

\section{References}

1. Pranzini, E. Coastal erosion and shore protection. In Encyclopedia of Vernacular Architecture; Vellinga, M., Ed.; Bloomsbury Publishing: London, UK, 2018; in press.

2. Jayakumar, K.; Malarvannan, S. Assessment of shoreline changes over the Northern Tamil Nadu Coast, South India using Web GIS techniques. J. Coast. Conserv. 2016, 20, 477-487. [CrossRef]

3. Morton, R.A.; Barras, J.A. Hurricane Impacts on Coastal Wetlands: A Half-Century Record of Storm-Generated Features from Southern Louisiana. J. Coast. Res. 2011, 27, 27-43. [CrossRef]

4. Young, K.R.; León, B. Natural Hazards in Peru: Causation and Vulnerability. Dev. Earth Surf. Process. 2009, $13,165-180$.

5. Nicholls, R.J. Rising sea levels: Potential impacts and responses. In Global Environmental Changes; Hester, R.E., Harrison, R.M., Eds.; Royal Society of Chemistry: Cambridge, UK, 2002; Volume 17, pp. 83-107.

6. Jiang, W.; Tao, C. The seawall in Quintang estuary. In Engineered Coasts; Chen, J., Eisma, D., Hotta, K., Walker, H.J., Eds.; Kluwer Academic Publishers: Dordrecht, The Netherlands, 2002; pp. 139-150.

7. Wang, L.; Xie, Y.; Wu, Y.; Guo, Z.; Cai, Y.; Xu, Y.; Zhu, X. Failure mechanism and conservation of the ancient seawall structure along Hangzhou Bay, China. J. Coast. Res. 2012, 28, 1393-1403. [CrossRef]

8. Nieuwhof, A. Living in a dynamic landscape: Prehistoric and proto-historic occupation of the northern-Netherlands coastal area. In Science for Nature Conservation and Management: The Wadden Sea Ecosystem and EU Directives, Proceedings of the 12th International Scientific Wadden Sea Symposium, Wilhelmshaven, Germany, 30 March-3 April 2009; Marencic, H., Eskildsen, K., Farke, H., Hedtkamp, S., Eds.; Common Wadden Sea Secretariat: Wilhelmshaven, Germany, 2010. 
9. Bazelmans, J.; Gerrets, D.A.; de Koning, J.; Vos, P.C. Zoden aan de dijk: Kleinschalige dijkbouw in de late prehistorie en protohistorie van noordelijk Westergo. De Vrije Fries 1999, 79, 7-73.

10. Bazelmans, J. Die Wurten von Dongjum-Heringa, Peins-Oost und Wijnaldum-Tjitsma: Kleinmaßstäblicher Deichbau in ur- und frügeschichtlicher Zeit des nördlichen Westergo. In Kulturlandschaft Marsch. Natur-Geschichte-Gegenwart; Landesmuseum für Natur und Mensch: Oldenburg, Germany, 2005; pp. 68-84.

11. Niemeyer, H.D.; Eiben, H.; Rohde, H. History and heritage of German coastal engineering. In History and Heritage of Coastal Engineering; Krauss, N.C., Ed.; ASCE: New York, NY, USA, 1996; pp. 169-213.

12. Van der Meulen, F.; van der Valk, B.; Arens, B. The Netherlands. In Coastal Erosion and Protection in Europe; Pranzini, E., Williams, A.T., Eds.; Routledge: London, UK, 2013; pp. 136-157.

13. Charlier, R.H. Belgian coastal erosion. Prof. Geogr. 1955, 7, 10-12. [CrossRef]

14. Kraus, N.C. History and Heritage of Coastal Engineering; American Society of Civil Engineers: New York, NY, USA, 1996; p. 45.

15. Cresy, E. An Encyclopedia of Civil Engineering; Longman: Harlow, UK, 1847.

16. Kraus, C.N.; McDougal, W.G. The Effects of Seawalls on the Beach: Part I, An Updated literature Review. J. Coast. Res. 1996, 12, 691-701.

17. Franco, L. History of Coastal Engineering in Italy; American Society of Civil Engineers: New York, NY, USA, 1996; pp. 275-335.

18. Blaeu, J. Vlissingen in Toonneel der Steden van de Vereenighde Nederlanden, Met Hare Beschrijvingen, 1652. Available online: http:/ / objects.library.uu.nl/reader/index.php?obj=1874-237713\&lan=en\#page//52/21/ 31/52213138426633615601451169782851892476.jpg/mode/1up (accessed on 29 June 2018).

19. Pranzini, E. Coastal erosion and shore protection: A brief historical analysis. J. Coast. Conserv. 2017, 1-4. [CrossRef]

20. Seutter, M. Novissima Ichnographica Delineatio Munitissimae Urbis et Celeberrimi Emporii Ostendae. In Comitatu Flandriae Austriacae Sitae, cur et Coela Matthaei Seutteri; Private Collection E.P.; Seutter, Mathaeus: Augsburg, Germany, 1734.

21. Baldacci, O. Le carte nautiche e il portolano di Bartolomeo Crescenzio. In Rendiconti della Classe di Scienze Morali, Storiche e Filologiche; Accademia Nazionale dei Lincei: Roma, Italy, 1949; Volume 4, pp. 601-635.

22. Lepore, F.; Piccardi, M.; Pranzini, E. Latitudine senza latitudine. Determinazioni astronomiche e carte per navigare dell'Europa tardo medievale: Le innovazioni di Francesco Beccari. Studi Costieri 2017, 27, 33-108.

23. Van der Aa, B. Le Port de Callao de Lima dans l'Amerique in La Galerie Agréable du Monde, où L'on Voit en un Grand Nombre de Cartes Très Exactes et de Belles Tailles Douces Les Principaux Empires, Roïaumes, Républiques, Provinces, Villes, Bourgs et Forteresses, Tome Second d'Amerique 1729. Available online: http:/ / gallica.bnf.fr/ark: /12148/btv1b10509759w.r=btv1b10509759w?rk=21459;2 (accessed on 29 June 2018).

24. Montanus, A.; van Meurs, J. De Nieuwe en Onbekende Weereld of Beschryving van America en 't Zuid-Land, Vervaetende D'oorsprong der Americaenen en Zuid-Landers, Gedenkwaerdige Togten Derwaerds, Gelegendheid der Vaste Kusten, Eilanden, Steden, Sterkten, Dorpen, Tempels, Bergen, Fonteinen, Stroomen, Huisen, De Natuur Van Beesten, Boomen, Planten en Vreemde Gewasschen, Gods-Dienst en Zeden, Wonderlijke Voorvallen, Vereeuwde en Nieuwe Oorloogen: Verciert Met af-Beeldsels na 't Leven in America Gemaekt Amsterdam, 1671. Available online: https://archive.org/stream/ denieuweenonbeke00mont\#page/n5/mode/2up (accessed on 29 June 2018).

25. Saeghman, G.J. Journael van de Nassausche Vloot, Zijnde een Beschryvingh van de Voyagie om den Gantschen Aerdt-Kloot, Gedaen Met Elf Schepen, Onder 't Beleydt Vanden Admirael Jaques l'Heremite, Ende Vice-Admirael Geen Huygen Schapenham, Inde Jaren 1623, 1624, 1625, en 1626; Gillis Joosten Saeghman: Amsterdam, The Netherlands, 1663.

26. Unknown, Vertoning van't Callao de Lima (De Vloot Voor Anker bij Callao, 1624), [ed.] 1663 ca. Available online: https: / www.rijksmuseum.nl/nl/ collectie/RP-P-OB-80.316 (accessed on 29 June 2018).

27. Arrús, D. El Callao en La Época del Coloniaje Los Antes y Despues de la Catástrofe de 1746 Posicion Real y Efectiva de la Ciudad Real, en Relación Con el Antiguo Presidio. Fundación de Bellavista. Terremotos Piratas Y, Datos Histórico-Cronológicos de los Virreyes y Gobernadores del Perú y de los Sucesos Más Reservas Notables Desde 1530 á 1829, Imprenta de El Callao, Callao 1904. Available online: https:/ / archive.org/ details/elcallaoenlapoc00arrgoog (accessed on 29 June 2018). 
28. Frézier, A.F. Plan de la Rade du Callao in Relation Du Voyage De La Mer Du Sud Aux Côtes Du Chily Et DuPerou, A Paris, 1716. Available online: https:/ / www.e-rara.ch/zuz/doi/10.3931/e-rara-54648 (accessed on 29 June 2018).

29. Melo, R. El Callao: Geographic Historical Monograph, Librería e Imprenta Gil ed.; 1899-1900. Available online: http:/ / bdh-rd.bne.es / viewer.vm?id=0000042274\&page=1 (accessed on 29 June 2018).

30. Lohmann Villena, G. Las Defensas Militares de Lima y Callao Hasta 1746; C.S.I.C: Sevilla, Spain, 1964.

31. Engels, F. Early Sites on the Peruvian Coast. Southwest. J. Anthropol. 1957, 13, 54-68. [CrossRef]

32. Silgado, F.E. Historia de los Sismos Mas Notables Ocurridos en el Peru: 1513-1974. Primera Edicion Digital, Víctor López Guzmán, Lima. 2012. Available online: http://www.guzlop-editoras.com/web_des/ing01/ ingsismica/pld0579.pdf (accessed on 29 June 2018).

33. Lemoine Fecit, Plan de la Ville du Callao, (1724-1727). Available online: http://gallica.bnf.fr/ark:/12148/ btv1b53122271w.r=btv1b53122271w?rk=21459;2 (accessed on 29 June 2018).

34. Frézier, A.F. Relation Du Voyage De La Mer Du Sud Aux Côtes Du Chily Et Du Perou; Printed for Jonah Bowyer: London, UK, 1717; Available online: https:/ / archive.org/details/voyagetosouthse00frzi (accessed on 29 June 2018).

35. Lemoine (Attr.) Plan de la Ville de Callao Avec ses Nouveaux Projets, (1724-1727). Available online: http:/ / gallica.bnf.fr/ark:/12148/btv1b53123330h.r=btv1b53123330h?rk=21459;2 (accessed on 29 June 2018).

36. Feuillée, L. Plan de la Ville de Callao Avec Ses Environs in Journal des Observations Physiques, Mathématiques et Botaniques, Faites par L'ordre du Roy sur les Côtes Orientales de l'Amérique Méridionale, et Dans les Indes Occidentales, Depuis L'année 1707, Jusques en 1712 et Dans un Autre Voiage Fait par le Même Ordre à la Nouvelle Espagne, \& Aux Isles de l'Amérique, 1725, Vol I. Available online: http:/ / www.e-rara.ch/zut/doi/10.3931/e-rara-1565 (accessed on 29 June 2018).

37. Rodríguez, N. Plano de Una Parte de la Plaze de Callao, Que Mira al Surgidereo, Comprebendida Desde el Muelle Real; Hasta el Rio de Pitipiti, en que se Demuestra el Estado en que al Presente se Hallan las Brechas que Avriò el Mar en Esta Parte de su Fortifacion, los Reparos en ella Costruydos, Las Playas Criadas Mediante el Beneficio de los Redientes o Muelles di Pioltage que se Han Exexutado [...]1728, Sevilla, Archivo General de Indias. Available online: http:/ / pares.mcu.es /ParesBusquedas/servlets /Control_servlet?accion=3\&txt_ id_desc_ud=22499\&fromagenda=N (accessed on 29 June 2018).

38. Silvester, R.; Hsu, J.R.C. Coastal Stabilization. Innovative Concepts; PRT Prentice Hall: Englewood Cliffs, NJ, USA, 1993; p. 539.

39. Segovia, S.R.; Mogollón, H.; Mayer, B. The Fortifications of Cartagena de Indias: Strategy and History; El Ancora Editores: Santafé, Bogotá, 1998.

40. Taype Ramos, V.; Bird, E.C.F. Peru. In Encyclopedia of the World's Coastal Landforms; Bird, E.C.F., Ed.; Springer: Dordrecht, The Netherlands, 2010; pp. 207-211.

41. Ordoñez, A. Descrypcyon de la Cyudad de Lyma y Puerto del Callao, 1768 (Copy). Available online: http:/ / bdh.bne.es/bnesearch/detalle/bdh0000032258 (accessed on 29 June 2018).

42. Pranzini, E.; Williams, A.T. (Eds.) Coastal Erosion and Protection in Europe, 1st ed.; Routledge: London, UK, 2013; p. 457.

43. Douglas, B.C.; Kearney, M.S.; Leatherman, S.P. Sea Level Rise: History and Consequences; Academic Press: San Diego, CA, USA, 2001; p. 232.

44. Williams, A.T.; Rangel-Buitrago, N.; Pranzini, E.; Anfuso, G. The management of coastal erosion. Ocean Coast. Manag. 2018, 156, 4-20. [CrossRef]

(c) 2018 by the authors. Licensee MDPI, Basel, Switzerland. This article is an open access article distributed under the terms and conditions of the Creative Commons Attribution (CC BY) license (http://creativecommons.org/licenses/by/4.0/). 